\section{Examining the Vascular Pathway of Sweet Cherries Grafted onto Dwarfing Rootstocks}

\author{
Mercy A. Olmstead, ${ }^{1}$ N. Suzanne Lang, ${ }^{2}$ and Gregory A. Lang ${ }^{3}$ \\ Department of Horticulture, Michigan State University, East Lansing, MI 48824
}

Frank W. Ewers ${ }^{3}$

Department of Plant Biology, Michigan State University, East Lansing, MI 48824

Shirley A. Owens ${ }^{4}$

Center for Advanced Microscopy, Michigan State University, East Lansing, MI 48824

Additional index words. confocal laser scanning microscopy, dye uptake, graft union, Safranin O, xylem

\begin{abstract}
Dye transport through vascular pathways was examined in tissues surrounding the graft union of second-leaf, field-grown trees of 'Lapins'/Gisela 5 ('Gi 5') (dwarfing) and 'Lapins'/'Colt' (nondwarfing). Excavated, intact trees were allowed to take up xylemmobile dye via transpiration for $6 \mathrm{~h}$ before sectioning the tree into scion, graft union, and rootstock tissue. 'Lapins'/'Gi 5' had a significantly larger stem cross-sectional area in the central graft union than did 'Lapins'/'Colt'. Per unit cross section, dye transport of both 'Lapins'/'Gi 5' and 'Lapins'/'Colt' was significantly less in the graft union than in rootstock sections, with still less transported to scion tissues in 'Lapins'/'Gi 5'. 'Lapins'/'Gi 5' had a tendency to produce vascular elements oriented obliquely to the longitudinal axis of the tree. Dye was distributed more uniformly axially and radially across the graft union in 'Lapins'/'Colt' than in 'Lapins'/'Gi 5', with an apparent accumulation of dye in 'Lapins'/'Gi $5^{\prime}$ ' graft union. Xylem vessel diameters and vessel hydraulic diameters $\left(V^{\prime} D_{h}\right)$ were smaller overall in 'Lapins'/'Gi 5' than in 'Lapins'/'Colt'; however, graft unions in both had smaller $V D_{h}$ than did rootstock sections. These observations suggest reduced transport efficiency of xylem vessels in the graft union in 'Lapins'/'Gi 5' may be due to smaller vessels, vascular abnormalities and/or increased amounts of callus and parenchyma tissue.
\end{abstract}

Dwarfing rootstocks have been used in a number of pomological systems to increase productivity and precocity, and to reduce both labor costs and chemical inputs. The availability of dwarfing rootstocks for sweet cherries (Prunus avium L.) is relatively recent (Gruppe, 1985) compared to that for apples (Malus domestica Borkh.) (e.g., Beakbane and Thompson, 1939; Beakbane, 1953). Research on the horticultural and physiological effects of dwarfing cherry rootstocks is relatively limited (Blaunsa et al., 2000; Edin et al., 1996; Whiting and Lang, 2004) and the scientific community has not definitively agreed upon the mechanisms of dwarfing in any perennial system (Atkinson et al., 2003; Jones, 1974; Kamboj et al., 1999; Sommelidou et al., 1994a, 1994b).

A number of hypotheses have been proposed to describe the dwarfing effect of rootstocks on scion growth. These include physical limitations caused by whorls of vas-

Received for publication 16 Nov. 2005. Accepted for publication $8 \mathrm{Jan}$. 2006. The authors would like to gratefully acknowledge staff and students at the HTRC in East Lansing, MI for their assistance.

${ }^{1}$ Former graduate student. To whom reprints should be addressed; e-mail:molmstead@wsu.edu.Current address: WSU-IAREC, 24106 N. Bunn Rd., Prosser, WA 99350

${ }^{2}$ Associate professor.

${ }^{3}$ Professor:

${ }^{4}$ Academic specialist. cular tissue (Simons, 1986, 1989); decreases in plant hormone concentrations and/or hormone ratios between scion and rootstock (Kamboj et al., 1999; Sommelidou et al., 1994b); increases in carbohydrate concentrations in scion tissue because of vascular incompatibility or physical limitations (Bieleski, 2000; Breen, 1975; Tabuenca, 1962); and decreases in water movement through the graft union (Atkinson et al., 2003; Gur and Blum, 1975). While there have been significant advances based on this collective work, no single report has satisfactorily explained the mechanism of dwarfing.

Transport of water, metabolites, and/or plant hormones may decrease through the graft union due to anomalies that develop during vascular differentiation between tissues of dwarfing combinations. Interestingly, the degree of reduced transport may be related to the degree of dwarfing imparted by a particular rootstock. In apples, roots of dwarfing rootstocks [e.g., 'Malling 27' ('M.27')] had lower hydraulic conductances than roots of semi-dwarfing rootstocks [e.g., 'Malling-Merton 106'('MM.106');Atkinson et al., 2003]. This may be associated with factors like lower xylem:phloem ratios and abnormalities in xylem anatomy of dwarfing rootstock systems (Atkinson et al., 2003; Beakbane and Thompson, 1947).

The development of vascular abnormalities (e.g., the production of excess callus cells in the graft union) may reduce xylem water trans- port and contribute to the dwarf stature. For example, whorls of xylem vessels in the graft union were associated with increased dwarfing in apple (Mosse, 1962; Simons, 1986). Additionally, vascular tissue that develops at acute angles contrary to the longitudinal axis of the tree could hinder transport. The incidence of highly angled xylem rays has been correlated with the degree of dwarfing conferred by an apple rootstock (Simons, 1986, 1989). 'Gisela 5', a . cerasus $\times$ P. canescens hybrid dwarfing rootstock for sweet cherry, developed a high frequency of xylem vessels at acute angles to the longitudinal axis of the tree (Olmstead, 2004). Misalignment of xylem vessels can occur as callus cells differentiate into vessels and parenchyma cells following grafting.

Many macroscopic and microscopic techniques have been developed to examine vascular elements (Czymmek et al., 1994; Simons, 1972), including the uptake or injection of dye (Atkinson et al., 2003; Oparka and Santa Cruz, 2000; Thompson and Schulz, 1999). Whole trees can be uprooted and transferred into a solution of a transportable dye (e.g., Safranin $\mathrm{O})$, then sectioned for visual and microscopic examination (Atkinson et al., 2003; Ellmore and Ewers, 1986). This technique can be used to determine whether limitations in water transport are due to mechanical blockage. Safranin $\mathrm{O}$ is transported in the transpiration stream, but is not exclusive to the vascular pathway. However, this dye renders a unique view of the vascular system by diffusing into areas with lignified cell walls, which can highlight axial and radial water movement.

Another barrier to axial water transport may be an increase in the proportion of callus tissue found surrounding the graft union (Asante and Barnett, 1997; Yang-Xiong et al., 1995). As the parenchyma cells of callus tissue differentiate into vascular elements, the tissue has a high metabolic demand and hence, water transport also increases. Preliminary research has suggested that soluble sugars accumulate above the graft union in dwarfing sweet cherry combinations, perhaps due to the demand of the differentiating callus tissue (Olmstead, 2004). Examining dye transport into this tissue may aid in explaining the 'swelling' of the graft union often observed in scions grafted onto certain rootstocks, and specifically sweet cherry scions grafted onto dwarfing rootstocks.

The objective of this research was to examine xylem structure and function in intact, immature sweet cherry trees grafted onto a dwarfing and a nondwarfing rootstock as a first step in attempting to understand water transport through the graft union. It was hypothesized that transport of water and Safranin O dye into scion tissues would be reduced in dwarfing combinations due to excess callus tissue surrounding the graft union and/or mechanical blockages that develop, and that smaller vessel diameters are more prevalent in the graft union of dwarfing rootstocks.

\section{Materials and Methods}

In April 2003, 2-year-old nursery budgrafted trees were field-planted at the MSU 
Horticulture Research and Teaching Center, East Lansing, Mich., in a well-drained Marlette fine sandy loam, with a minor slope ( $2 \%$ to $6 \%)$. Trees were comprised of either 'Gi 5' (dwarfing) or 'Colt' (nondwarfing) rootstocks with 'Lapins' as the scion. Both 'Gi 5' and 'Colt' are clonally propagated rootstocks, as opposed to the standard vigorous rootstocks used in the U.S., which are genetically heterogeneous seedlings of $P$. avium (Mazzard) or $P$. mahaleb. Spacing was $1.8 \mathrm{~m}$ between trees and $3.0 \mathrm{~m}$ between rows. The trees were planted in a completely randomized design with rootstock type as the main treatment. The orchard floor consisted of grass alleys and in-row herbicide strips. Trees were fertilized as necessary and irrigated at a rate of about $2.5 \mathrm{~cm}$ per week.

At the time of rapid shoot expansion $(0.7$ to $1.0 \mathrm{~mm} \cdot \mathrm{d}^{-1}$; Fig. 1), 10 whole-tree replicates of each scion-rootstock combination were excavated to include as much of the root system as possible, thereby minimizing disruption of the water column. Trees were transported in sealed polyethylene bags to buckets of fresh water, where they were immersed and then cut underwater to minimize embolisms. Trees were severed about $2 \mathrm{~cm}$ above the rootshank and about $5 \mathrm{~cm}$ below the graft union to maximize the length of rootstock stem. The tree was then transferred into a filtered solution of aqueous $0.1 \%$ Safranin O dye $(\mathrm{w} / \mathrm{v})$ (Sperry et al., 1988). Trees were allowed to transpire in full sunlight (maximum global irradiance about $1250 \mathrm{~W} \cdot \mathrm{m}^{-2}$ ) on a clear day for $6 \mathrm{~h}$, then were cut into three transverse and three longitudinal sections centered on the graft union $(3$ to $5 \mathrm{~cm}$ long), and section locations were categorized as 1) scion tissue (5 $\mathrm{cm}$ above the graft union); 2) central graft union tissue; and 3) rootstock tissue ( $5 \mathrm{~cm}$ below the graft union). Macroscopic images were recorded digitally (Olympus C700UZ, Melville, N.Y.). Tissues were further sectioned into $120 \mu \mathrm{m}$ thick transverse slices using a sliding microtome. Individual tissue replicates ( $\mathrm{n}=10$ per location) were examined by fluorescence microscopy (Zeiss LSM Pascal, Jena, Germany; argon 488-nm laser line, $73-\mu \mathrm{m}$ pinhole aperture, and a 520-nm-long pass filter) to quantify functional xylem across the stem and graft union. Functional xylem in each section was determined as limited to the first two outermost growth rings as indicated by fluorescence. Safranin O has a peak excitation wavelength of $488 \mathrm{~nm}$ and a peak emission wavelength of $530 \mathrm{~nm}$. Unstained samples of the same tissue were observed using the same microscopic parameters to ensure that the fluorescence signal was not from autofluorescence.

Microscopic images were analyzed using the trace measurement tool and macroscopic images were measured using color and intensity thresholds in Sigma Scan Pro 5.0 (Systat Software Inc., Richmond, Calif.; Olmstead et al., 2004). The image was calibrated to a known dimension, and the desired anatomical feature measured by defining two points. Macroscopic images of transverse slices were analyzed using the color threshold tool, in which a range of color is selected for measurement. The entire cross section was analyzed, including bark, to ensure that dye was sequestered primarily to xylem vessels. Single-layer microscopic images of fluorescing vessels were converted to a grayscale image and analyzed using an intensity threshold to determine percent uptake per unit cross-sectional area $(\mathrm{n}=10)$. The percent area stained in rootstock slices was considered as the maximum possible value. Subsequent slices of scion and graft union sections were compared with the rootstock to determine whether dye accumulated or declined in intensity in the acropetal direction (from below to above the graft union) through the sections.

Randomly selected vessels within the vascular pathway (i.e., area of maximum water transport) were chosen for measurement $(\mathrm{n}=$ 25 ). Vessel diameter(VD) was determined from the mean of two perpendicular measurements across the widest part of the vessel lumen. This was then averaged for all vessels within the area of maximum water transport.

Vessel hydraulic diameters $\left(\mathrm{VD}_{\mathrm{h}}\right)$ were calculated to determine the hydraulic efficiency of xylem vessels in scion, graft union, and rootstock tissue. By Poiseuille's Law, the rate of fluid flow through a cylinder is proportional to the fourth power of the cylinder's radius (Nobel, 1999; Zimmerman, 1983). Thus, narrow vessels often contribute little to overall hydraulic efficiency. Because wider vessels contribute proportionally more per unit diameter to the overall hydraulic conductivity of the stem than do narrow vessels, a large number of narrow vessels in a population may not accurately represent potential hydraulic function. By "hydraulically weighting" the vessel diameters, distributions of vessel sizes among stem segments can be compared for potential functional efficiency (Pockman and Sperry, 2000). Vessel hydraulic diameter is defined as $\Sigma d^{5} / \Sigma d^{4}$ where $d$ is vessel diameter $(\mu \mathrm{m})$.

General linear models (GLM) were used as appropriate, with alpha levels set at 0.05 a priori. Data were tested for normality with homogeneous variances and for continuity. When normality was not satisfied, data were transformed logarithmically. Mean separation was by Tukey's HSD and Fisher's LSD as appropriate (SAS Institute; Cary, N.C.).

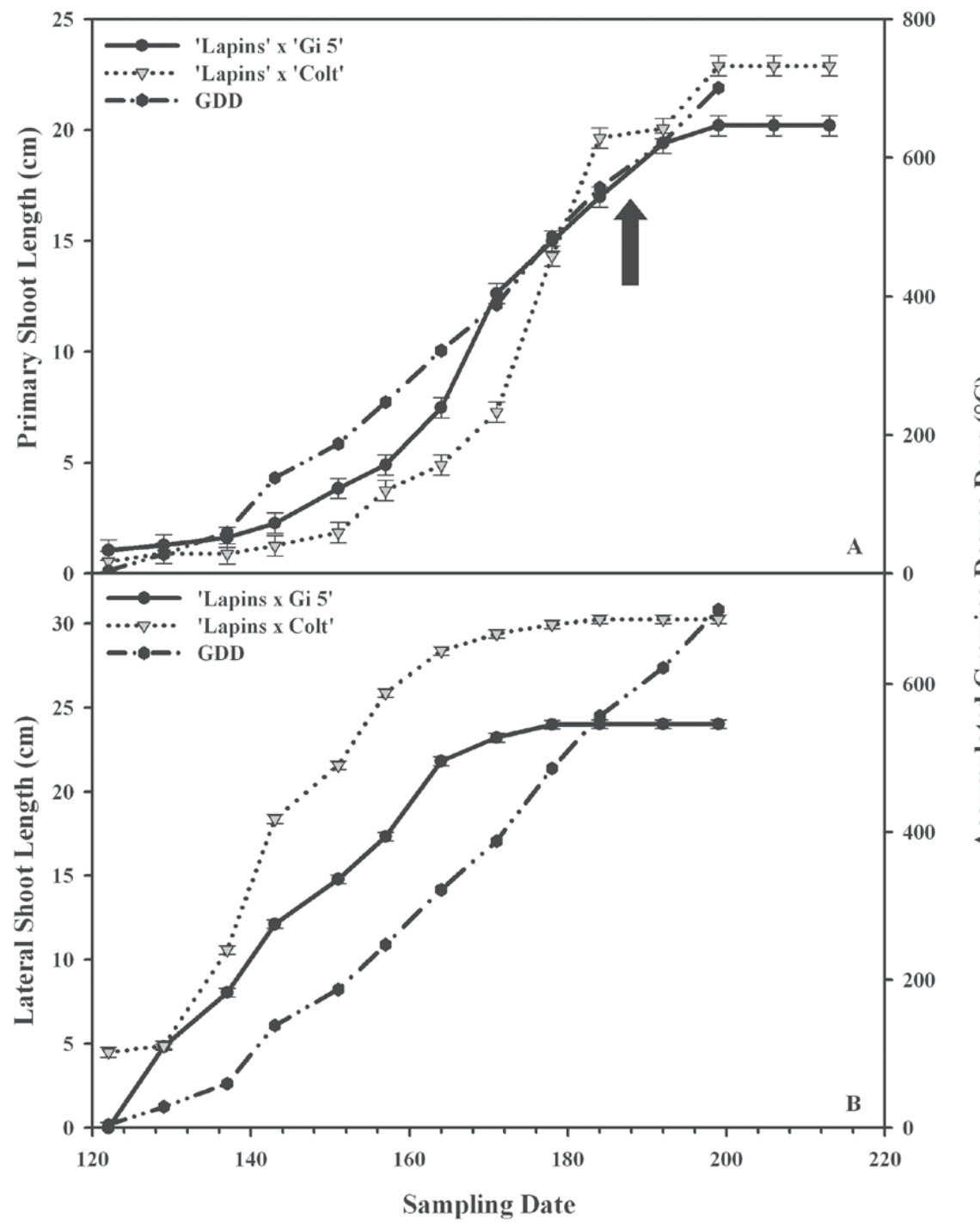

Fig. 1. Primary shoot length (A) and current year lateral growth (B) as recorded for 'Lapins'/'Gi 5' and 'Lapins'/'Colt' trees in East Lansing, Mich., in 2003. Arrow indicates when trees were harvested for dye uptake experiment. Error bars represent $\pm \operatorname{SE}(n=10)$. 

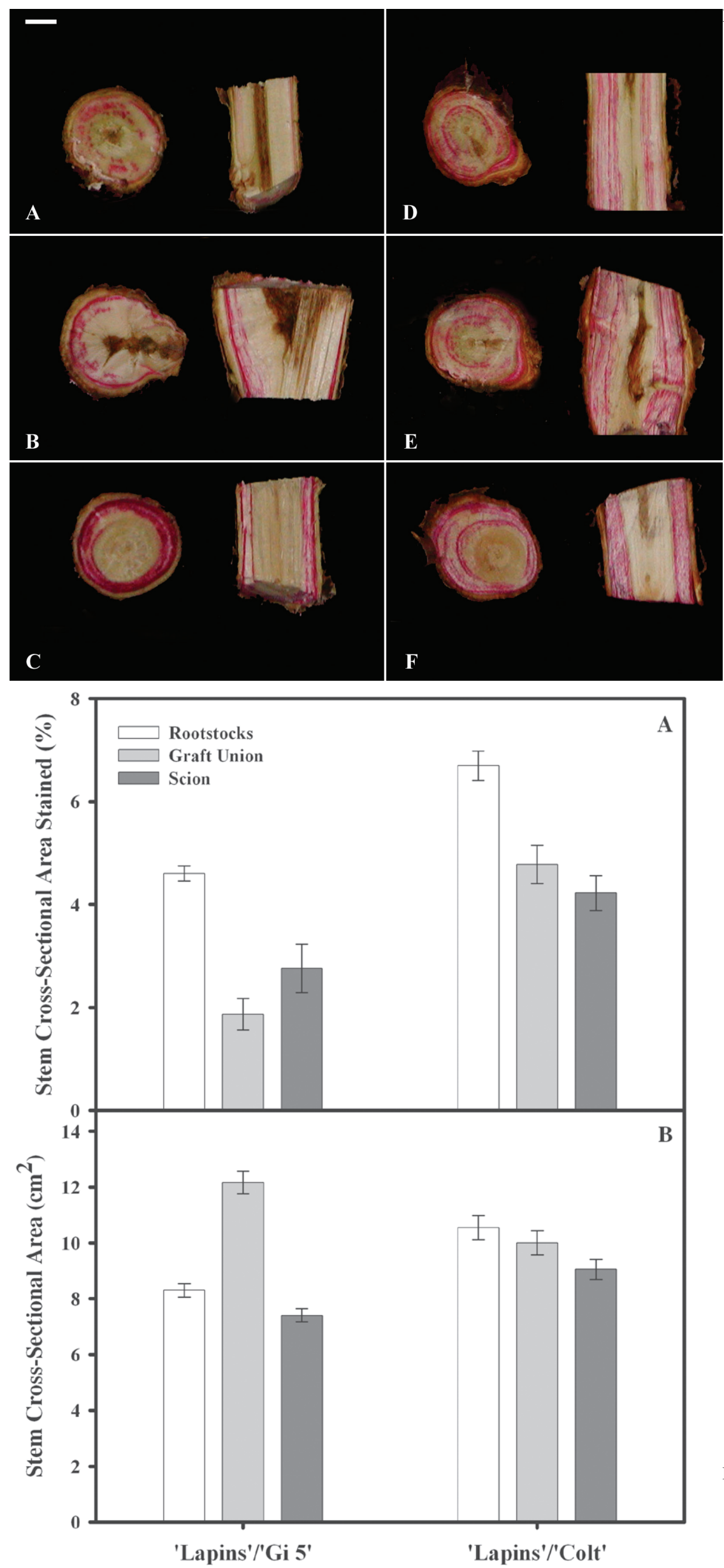

Fig. 2. Visualization of water uptake and transport through sweet cherry/rootstock stem sections of a dwarfing ('Lapins'/'Gi 5', A-C) and a nondwarfing ('Lapins'/'Colt', D-F) combination. An aqueous $0.1 \%$ Safranin O solution was taken up by intact stem sections for $6 \mathrm{~h}$ in full sunlight; (A and $\mathbf{D})$ scion, ( $\mathbf{B}$ and $\mathbf{E})$ graft union, $(\mathbf{C}$ and $\mathbf{F})$ rootstock. Images are representative of all samples $(n=10)$. Scale bar $=1 \mathrm{~cm}$.

\section{Results}

In both dwarfing and nondwarfing trees, dye was transported in the two outermost growth rings (Fig. 2). Dye uptake in 'Lapins'/'Colt' was distributed more uniformly radially across graft union tissue and longitudinally throughout the sections than in 'Lapins'/'Gi 5', suggesting that more water was transported through all sections in 'Lapins'/'Colt' (Fig. 3A). This effect was especially visible longitudinally (Figs. 2A-F). Graft union tissue in 'Lapins'/'Gi 5 ' had significantly less stem area stained than the scion or rootstock tissues of either combination $(P<0.01)$ (Fig. 3A). Overall, staining was significantly greater in all tissues of 'Lapins'/'Colt' than in their 'Lapins'/'Gi 5' counterparts.

In both 'Lapins'/'Gi 5' and 'Lapins'/'Colt', scion sections had the smallest stem crosssectional area as compared to the graft union or rootstock sections $(P \leq 0.05)$ (Figs. $2 \mathrm{~A}$ and $\mathrm{D}$ and $3 \mathrm{~B})$. Scion sections of 'Lapins'/'Gi 5' had the smallest stem cross-sectional area of all tissues examined (Fig. 3B). Conversely, graft unions of 'Lapins'/'Gi 5' consistently had larger stem diameters than any other section examined in either combination (Figs. 2A-C and 3B). In 'Lapins'/'Colt', stem diameter steadily decreased from rootstock to scion (Fig. 3B).

Despite its large cross-sectional area, the area of functional water transport in the graft union of 'Lapins'/'Gi 5'was proportionally less $(1.9 \% ; P=0.05)$ than any other tissue section (Fig. 3A) and represented the greatest decline in area stained (59\%) relative to the adjacent rootstock section. 'Lapins'/'Colt' exhibited a gradual decrease in dye uptake from rootstock to scion, with a more moderate decline $(29 \%)$ between rootstock and graft union. The greater decline in percent stained area for 'Lapins'/'Gi 5 ' suggests that differences in area of functional water transport between rootstock and scion is consistent with observed dwarfing effects on tree vigor.

Safranin $O$ staining in scion tissue of 'Lapins'/'Gi 5' was less than that of 'Lapins'/'Colt' (Fig. 4). Furthermore, only a small number of vessels were functional as indicated by those vessels emitting fluorescence in 'Lapins'/'Gi 5' compared to the number of functional vessels present in 'Lapins'/'Colt' scion tissue (Fig. 4A and D). In either combination, VD was smaller in the graft union than in the rootstock, but there

Fig. 3. Percentage stained (A) and total (B) stem crosssectional areas from transverse sections of rootstock, graft union, and scion tissues of 'Lapins'/'Gi 5' and 'Lapins'/'Colt'sweet cherry/rootstock combinations. Error bars represent \pm SE $(\mathrm{n}=10)$. 


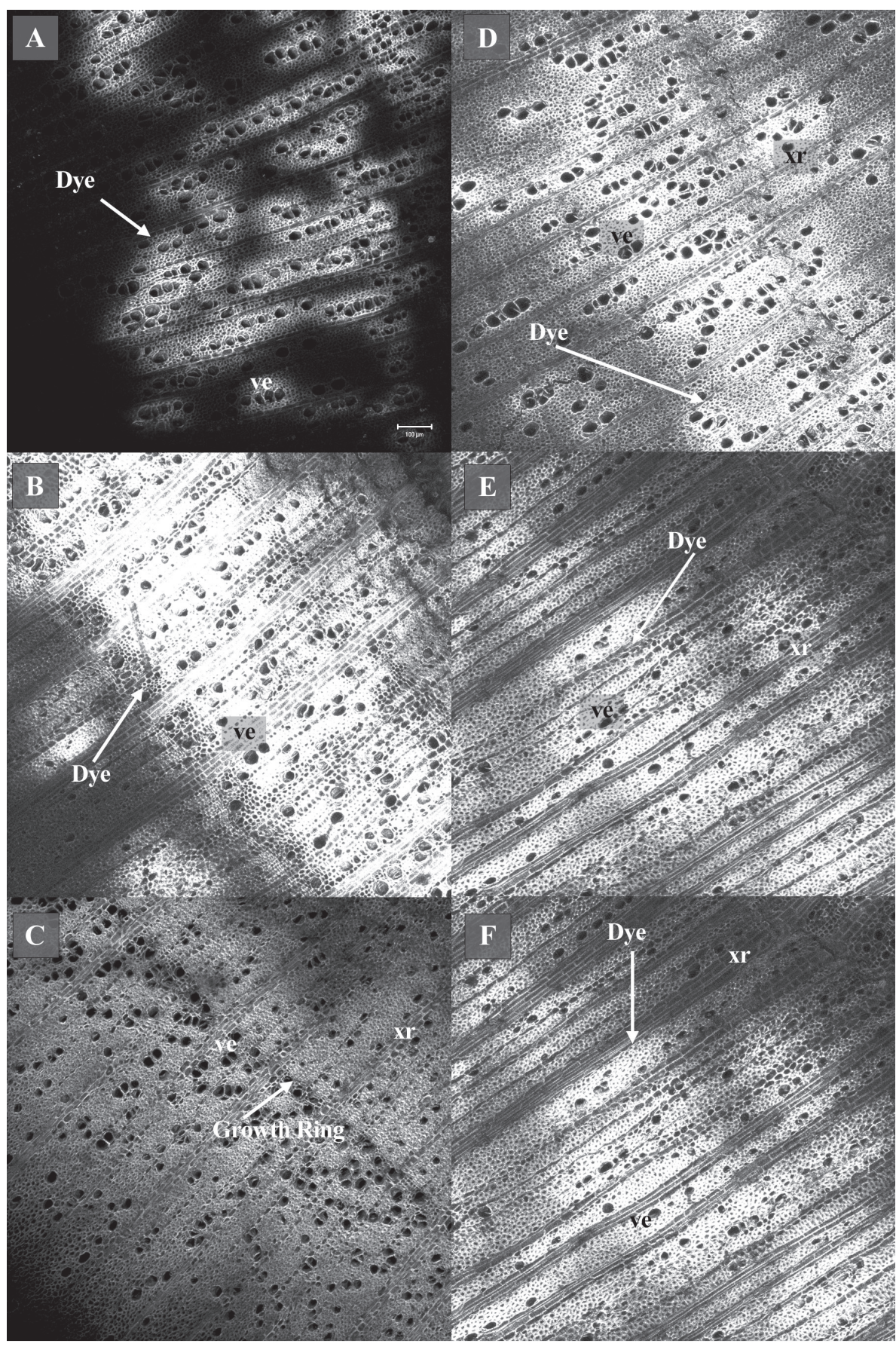

Fig. 4. Extended focus fluorescence images comparing Safranin O uptake in xylem tissue of 'Lapins'/'Gi 5' (A-C) and 'Lapins'/'Colt' (D-F). A growth ring is visible in the dyed area of the rootstock of 'Lapins'/'Gi 5' (C). (A and D) scion, (B and E) graft union, (C and F) rootstock; ve = vessel element, $\mathrm{xr}=$ xylem rays. Scale $\mathrm{bar}=100 \mu \mathrm{m}$.

Table 1. Xylem vessel characteristics for 'Lapins'/'Gi 5' (dwarfing) and 'Lapins'/'Colt' (nondwarfing).

\begin{tabular}{lcccc}
\hline Treatment & Section & $\begin{array}{c}\text { Vessel } \\
\text { diam }(\mu \mathrm{m})^{\mathrm{z}}\end{array}$ & $\begin{array}{c}\text { Hydraulic vessel } \\
\text { diam }(\mu \mathrm{m})^{\mathrm{z}}\end{array}$ & $\begin{array}{c}\text { Maximum vessel } \\
\text { diam }(\mu \mathrm{m})^{\mathrm{z}}\end{array}$ \\
\hline 'Lapins'/'Gi 5' & Scion & $32.2 \pm 0.5 \mathrm{bc}^{\mathrm{x}, \mathrm{w}}$ & $37.2 \pm 0.5 \mathrm{~b}$ & 49.4 \\
& Graft union & $31.2 \pm 0.5 \mathrm{c}$ & $35.8 \pm 0.5 \mathrm{~b}$ & 46.3 \\
& Rootstock & $33.2 \pm 0.4 \mathrm{~b}$ & $37.8 \pm 0.4 \mathrm{~b}$ & 52.0 \\
'Lapins'/'Colt' & Scion & $37.2 \pm 0.5 \mathrm{a}$ & $42.7 \pm 0.5 \mathrm{a}$ & 57.3 \\
& Graft union & $32.0 \pm 0.5 \mathrm{c}$ & $38.8 \pm 0.5 \mathrm{~b}$ & 51.6 \\
& Rootstock & $39.0 \pm 0.6 \mathrm{a}$ & $45.6 \pm 0.6 \mathrm{a}$ & 65.3 \\
\hline
\end{tabular}

${ }^{\mathrm{z}} \mathrm{n}=10$ trees.

${ }^{y} n=25$ vessels.

${ }^{\mathrm{x}}$ Diameter reported $\pm \mathrm{SE}$.

${ }^{\mathrm{w}}$ Letters denote mean separation within columns by LSD at $P \leq 0.05$. was no difference between the graft union and scion in 'Lapins'/'Gi 5' (Table 1). Although VD in the graft union of 'Lapins'/'Colt' and 'Lapins'/'Gi 5' were statistically the same, this did not significantly affect potential water transport based on dye movement (Fig. 3A). Examination of the microscopic images reveals that the graft union in 'Lapins'/'Gi 5' accumulated more dye than in scion tissues (Figs. 4A-C and 5). Additionally, functional vascular elements in 'Lapins'/'Colt' were dispersed laterally across the stem, allowing radial diffusion into parenchyma surrounding the vessels (Fig. 4D-F).

Vessel diameters in areas of maximum dye transport (i.e, stained areas) were significantly smaller in graft union tissue $(31.2 \mu \mathrm{m})$ than in rootstock tissue $(33.2 \mu \mathrm{m})(P<0.05$; Table 1$)$ of ' $\mathrm{Gi}$ 5', although VD did not differ between scion and graft union. 'Lapins'/'Colt' also had significantly smaller vessels in the graft union $(32.0 \mu \mathrm{m})$ than in either the scion or rootstock $(P<0.001$, Table 1$)$. Overall, VD and maximum vessel diameters were smaller in 'Lapins'/'Gi 5' than in 'Lapins'/'Colt'. Maximum vessel diameter in areas of maximum dye transport exhibited a similar trend, with the lowest value in graft union sections for both rootstock treatments.

Vessel hydraulic diameter was smallest in the graft union tissues of both treatments, but differed from $\mathrm{VD}_{\text {o }}$ of either scion or stock only in 'Lapins'/'Colt' (Table 1). As with VD, overall VD of 'Lapins'/'Gi 5' was significantly smaller than 'Lapins'/'Colt'. This suggests that theoretical water flow in these vessels is less in 'Lapins'/'Gi 5' than in 'Lapins'/'Colt'.

\section{Discussion}

The scion is expected to have the smallest diameter along the stem of a young grafted tree (Hartmann et al., 1997), and this was the case for both 'Lapins'/'Gi 5' and 'Lapins'/'Colt'. Furthermore, the graft union of a young tree is expected to have the largest diameter along the axis of the tree stem, since it results from the outgrowth of a scion bud grafted onto an older rootstock. Most, if not all, cherry trees from North American nurseries are bud-grafted, and the process of grafting can have an impact on the formation of vessels that contribute to water transport (Olmstead et al., 2005). In this study, 'Lapins'/'Gi 5' had a larger graft union crosssectional area than 'Lapins'/'Colt'. Swelling in the graft union of apple (Simons and Chu, 1983) and cherry (Deloire and Hebant, 1983; Olmstead, 2004) trees on dwarfing rootstocks has been attributed to the proliferation of callus and parenchymatous tissue as the graft wound heals. This relatively young and continually differentiating tissue has a demand for sugars as cell walls lignify and for water to maintain turgor pressure.

Sweet cherry is classified as semi-ring porous with greatest water transport in mature xylem vessels of the outer growth rings or in the larger vessels of inner rings (Ellmore and Ewers, 1986;Zimmerman and Jeje, 1981). This pattern of xylem vasculature was observed here 


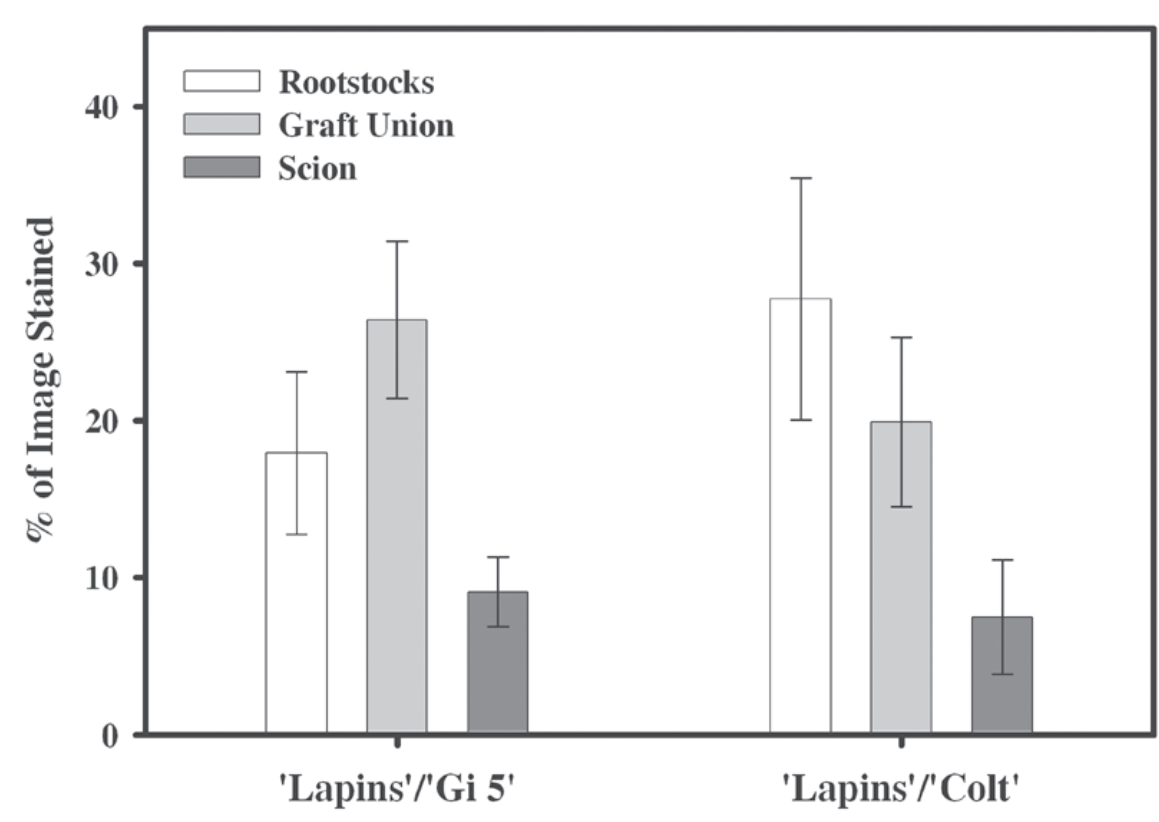

Fig. 5. Percent of microscopic image (single-layer) stained ( $0.1 \%$ Safranin $\mathrm{O})$ in the area of maximum water transport in a dwarfing ('Lapins'/'Gi 5') and a nondwarfing ('Lapins'/'Colt') sweet cherry/rootstock combination. Error bars represent $\pm \mathrm{SE}(\mathrm{n}=10)$

via dye uptake (Fig. 4A-F). In 'Lapins'/'Gi 5 , dye transport declined acropetally from the graft union, suggesting a reduction in the velocity of water flow. In fact, longitudinal sections revealed large sections of vascular tissue developed on a diagonal that may limit flow between graft union and scion regions in 'Lapins'/'Gi 5'.

A decrease in VD from the rootstock to graft union of 'Lapins'/'Gi 5' may have impeded water transport between the tissues. Both macroscopic and microscopic examination of dye staining and calculation of $\mathrm{VD}_{\mathrm{h}}$ suggested that the functional capacity of the vascular system of 'Lapins'/'Gi 5' was less than that of 'Lapins'/'Colt', which is in agreement with results from apple systems (Atkinson et al., 2003).

There were narrower vessels in 'Lapins'/'Gi 5' than in 'Lapins'/'Colt', which may be due to genetic differences, as it has been suggested that dwarfing rootstocks inherently produce smaller vessels (Beakbane and Thompson, 1947). Macroscopic examination suggests that rootstock selection affected water transport to a greater extent in 'Lapins'/'Gi 5' than in 'Lapins'/'Colt'.

The reduction of $\mathrm{VD}_{\mathrm{h}}$ from the rootstock to the graft union, which occurred in both 'Lapins'/'Gi 5' and 'Lapins'/'Colt', appears to affect water transport to a lesser degree in 'Lapins'/'Colt'. Perhaps water transport between vessels (i.e., lateral diffusion) in 'Lapins'/'Colt' may account for the increased dye uptake when compared to 'Lapins'/'Gi 5'. Smaller VD and $\mathrm{VD}_{\mathrm{h}}$, as well as reduced lateral diffusion, may contribute to the dwarfing generally observed when scions are grafted onto Gisela 5.

Vessel diameter is not the only factor to influence xylem water transport. In dwarfing apple rootstocks, vascular elements (e.g., vessels) may develop on a diagonal to the strictly physical resistance or due to metabolic control. Results on transpiration, water use efficiency (WUE), and photosynthetic rate of scions on dwarfing rootstocks have been contradictory in apples, with no difference in transpiration or photosynthesis between dwarfing and standard rootstock systems (Barden and Ferree, 1979), or lower rates of photosynthesis and transpiration in leaves of dwarfing rootstocks (Looney, 1968; Schechter et al., 1991). Water use efficiency has not correlated well with vigor. In 'Rainier'/'Gi 5', 'Rainier'/'Gi 6' and 'Rainier'/Mazzard, WUE of well-watered potted trees was not different, although 'Rainier'/'Gi 5' did transpire more rapidly (Zavalloni, 2004). Photosynthetic rates, transpiration and stomatal conductance of fully expanded leaves on 2-year-old 'Lapins' trees were significantly higher on 'Gi 5' than on 'Colt' (Olmstead, 2004). However, acropetal dye movement in 'Lapins'/'Colt' translocated further both vertically and radially than in 'Lapins'/'Gi 5'. Perhaps the increased deposition of callose and/or lignified cells in the graft union region of 'Lapins'/'Gi 5' resulted in the apparent reduction of dye in scion tissues. Further research is needed to understand how physiological and anatomical differences in dwarfing and nondwarfing cherry rootstocks affect scion photosynthesis, transpiration, and overall tree hydraulic parameters.

\section{Conclusions}

efrer ries, with development of xylem wood on a distinct diagonal (Fig. 2B). It is possible that the vascular pathway in dwarfing combinations is extended because of this vascular orientation. This longer pathway in the graft union may allow greater water diffusion into increased callus and parenchyma tissue that is present. Thus, water transport occurs along a longer pathway, as opposed to a physically restricted one (e.g., through smaller vessels). An elongated vascular pathway might trap water and allow larger molecules (e.g., dye) to diffuse into surrounding tissues. Longer pathways may slow water transport and solutes in the graft union (Fig. 2A-F), leading to the apparent reduction of dye uptake in the graft union and scion of 'Lapins'/'Gi 5' (Figs. 2A-C and 3A). This has implications for management, as reduced water transport can affect a number of processes during fruit development, particularly the third stage of cherry fruit growth, cell enlargement. Canopy leaf area and crop load should be balanced when growing sweet cherry scions on ' $\mathrm{Gi}$ 5 ' rootstocks. This may require pruning and fertilization strategies specifically designed for trees grafted onto ' $\mathrm{Gi} 5$ ' rootstocks.

An alternative hypothesis for the apparent reduction in water transport through the graft union is that there is a reduction in transpiration of 'Lapins'/'Gi 5' due to smaller evaporative surface area or perhaps rootscion signaling molecules such as ABA. An interesting follow-up experiment might be to compare water transport through living tissue vs. dead root-union-scion vascular sections to test whether transport is limited due to
Dye uptake and translocation patterns in stem tissues suggest that xylem flow may be reduced in dwarfing cherry scion-rootstock combinations. Overall, the graft union stem cross-sectional area was highest in 'Lapins'/'Gi 5 ' compared to all other stem sections in either 'Lapins'/'Gi 5' or 'Lapins'/'Colt'. There was a greater tendency for xylem vessels to be oriented at an angle to the longitudinal axis of the tree in the graft union of 'Lapins'/'Gi 5'. Thus, this greater cross-sectional area did not result in an increase in the stained area of functional transport. The percent of total area stained in the graft union of 'Lapins'/'Gi 5' was less than all other sections and treatment combinations.

Microscopic examination within areas of maximum transport suggested that the graft union of 'Lapins'/'Gi 5' accumulated dye, perhaps due to a reduction in the velocity of water transport. 'Lapins'/'Colt' had a more uniform distribution of dye throughout the scion, graft union, and rootstock tissues, hence more functional vessel elements. Vessel diameters were smallest for graft union tissues in both treatments.

In 'Lapins'/'Gi 5', reduced dye uptake may be caused by the combination of smaller vessel diameters and an increased amount of lignified tissue located in the graft union region, leading to increased avenues for $\mathrm{xy}$ lem content dispersal. Nonfunctional phloem and abnormal vascular pathways in the graft union may provide a longer route for water to travel, thus slowing water transport in the graft union region. 


\section{Literature Cited}

Atkinson, C.J., M.A. Else, and L. Taylor. 2003. Root and stem hydraulic conductivity as determinants of growth potential in grafted trees of apple (Malus pumila Mill.). J. Expt. Bot. 54:1221-1229.

Asante, A.K. and J.R. Barnett. 1997. Graft union formation in mango (Mangifera indica L.). J. Hort. Sci. 72:781-790.

Barden, J.A. and D.C. Ferree. 1979. Rootstock does not affect net photosynthesis, dark respiration, specific leaf weight, and transpiration of apple leaves. J. Amer. Soc. Hort. Sci. 104:526-528.

Beakbane, A.B. 1953. Anatomical structure in relation to rootstock behavior. Proc. Intl. Hort. Congr. 13:152-158.

Beakbane,A.B. and E.C. Thompson. 1939. Anatomical studies of stems and roots of hardy fruit trees. II. The internal structure of the roots of some vigorous and some dwarfing apple rootstocks, and the correlation of structure with vigour. J. Hort. Sci. 17:141-149.

Beakbane,A.B. and E. C. Thompson. 1947. Anatomical studies of stems and roots of hardy fruit trees. IV. The root structure of some new clonal apple rootstocks budded with Cox's Orange Pippen. J. Hort. Sci. 23:206-211.

Bieleski, R.L. 2000. The bigger picture-Phloem seen through horticultural eyes. Austral. J. Plant Physiol. 27:615-624.

Blaunsa, T., M.A. Else, C.J. Atkinson, and W.J. Davies. 2000. Solute content of xylem sap expressed from sweet cherry rootstocks with different dwarfing potentials. Plant Physiol. Biochem. 38:157.

Breen, P.J. 1975. Effect of peach/plum graft incompatibility on seasonal carbohydrate changes. J. Amer. Soc. Hort. Sci. 100:253-259.

Czymmek, K.J., J.H. Whallon, and K.L. Klomparens. 1994. Confocal microscopy in mycological research. Exp. Mycol. 18:275-293.

Deloire, A. and C. Hebant. 1983. Histophysiological study of the graft union of compatible and incompatible combinations of Prunus. Agronomie 3:207-212.

Edin, M., A. Garcin, J. Lichou, and J.M. Jourdain. 1996. Influence of dwarfing cherry rootstocks on fruit production. Acta Hort. 410:239-245.

Ellmore, G.S. and F.W. Ewers. 1986. Fluid flow in the outermost xylem increment of a ringporous tree, Ulmus Americana. Amer. J. Bot. 73:1771-1774.
Gruppe, W. 1985. An overview of the cherry rootstock breeding program at Giessen, 1965-1984. Acta Hort. 169:189-198.

Gur, A. and A. Blum. 1975. The water conductivity of defective graft unions in pome and stone fruits. J. Amer. Soc. Hort. Sci. 100:325-328.

Hartmann, H.T., D.E. Kester, F.T. Davies, Jr., and R.L. Geneve. 1997. Plant propagation. 6th ed. Prentice-Hall, Englewood Cliffs, N.J.

Jones, O.P. 1974. Xylem sap composition in apple trees. Ann. Bot. 38:463-467.

Kamboj, J.S., P.S. Blake, J.D. Quinlan, and D.A Baker. 1999. Identification and quantitation by GC-MS of zeatin and zeatin riboside in xylem sap from rootstock and scion of grafted apple trees. Plant Growth Regulat. 28:199-205.

Looney, N.E. 1968. Comparison of photosynthetic efficiency of two apple cultivars with their compact mutants. Proc. Amer. Soc. Hort. Sci. 92:34-36.

Mosse, B. 1962. Graft-incompatibility in fruit trees, p. 1-36. Commun. Agr. Bur. England Tech. Commun. No. 28.

Nobel,P.S. 1999. Physiochemical and environmental plant physiology. 2nd ed. Academic Press, San Diego, Calif.

Olmstead, M.A., N.S. Lang, G.A. Lang, F.W. Ewers, and S.A. Owens. 2005. Xylem vessel anatomy of sweet cherries grafted onto dwarfing and nondwarfing rootstocks. J. Amer. Soc. Hort. Sci. (in press)

Olmstead, M.A., R. Wample, S. Greene, and J. Tarara. 2004. Nondestructive measurement of vegetative cover using digital image analysis. HortScience 39:55-59.

Olmstead, M.A. 2004. Vascular and metabolic impact of dwarfing rootstocks on sweet cherry (Prunus avium L.). PhD diss. Mich. State Univ., East Lansing.

Oparka, K.J., and S. Santa Cruz. 2000. The great escape: Phloem transport and unloading of macromolecules. Annu. Rev. Plant Physiol. Mol. Biol. 51:323-347.

Pockman, W.T. and J.S. Sperry. 2000. Vulnerability to xylem cavitation and the distribution of Sonoran Desert vegetation. Amer. J. Bot. 87:1287-1299.

Schechter, I., D.C. Elfving, and J.T.A. Proctor. 1991. Apple tree canopy development and photosynthesis as affected by rootstock. Can. J. Bot. 69:295-300.

Simons, R.K. 1972. Scanning electron micros- copy for studies on plant material. Hort. Res. 12:73-75.

Simons, R.K. 1986. Graft-union characteristics as related to dwarfing in apple (Malus domestica Borkh.). Acta Hort. 160:57-66.

Simons, R.K. 1989. Growth characteristics of apple dwarfing rootstocks as related to lenticels, roots and the regenerative tissues within the union of stock and scion. Acta Hort. 243:87-88.

Simons, R.K. and M.C. Chu. 1983. Graft union development: Granny Smith/EM 26 - Specific growth characteristics between stock and scion. Compact Fruit Tree 16:73-82.

Soumelidou, K., N.H. Battey, J.R. Barnett, and P. John. 1994a. The anatomy of the developing bud union and its relationship to dwarfing in apple. Ann. Bot. 74:605-611.

Soumelidou, K., D.A. Morris, N.H. Battey, J.R. Barnett, and P. John. 1994b. Auxin transport capacity in relation to the dwarfing effect of apple rootstocks. J. Hort. Sci. 69:719-725.

Sperry, J.S., J.R. Donnelly, and M.T. Tyree. 1988. A method for measuring hydraulic conductivity and embolism in xylem. Plant Cell Environ. 11:35-40.

Tabuenca, M.C. 1962. Relaciones entre la composición química y el grado de compatibilidad en combinaciones de melocotonero y ciruelo. Anales de la Estaciâon Experimental de Aula Dei. 7:1-34 (English abstract).

Thompson, G.A. and A. Schulz. 1999. Macromolecular trafficking in the phloem. Trends in Plant Sci. 4:354-360.

Whiting, M.D. and G.A. Lang. 2004. Bing sweet cherry on the dwarfing rootstock Gisela 5: Crop load affects fruit quality and vegetative growth but not net $\mathrm{CO}_{2}$ exchange. J. Amer. Soc. Hort. Sci. 129:407-415.

Yang-Xiong, Li, L-Z., Shen, S-X. Ying, L-C., and Bao, M-L. 1995. Callus formation at graft interface in Ginkgo biloba L. Acta Bot. Sinica. 37:909-912.

Zavalloni, C. 2004. Evaluation of nitrogen-fertilizer uptake, nitrogen-use and water-use efficiency in sweet cherry (Prunus avium L.) on dwarfing and standard rootstocks. PhD diss. Mich. State Univ., East Lansing, Mich.

Zimmerman, M.H. and A.A. Jeje. 1981. Vessellength distribution in stems of some American woody plants. Can. J. Bot. 59:1882-1892.

Zimmerman, M.H. 1983. Xylem structure and the ascent of sap. Springer-Verlag, New York. 